\title{
(JIPD)
}

Jurnal Inovasi Pendidikan Dasar

Vol. 4, No. 2, Bulan Juli Tahun 2020, Hal. 110-114

E-ISSN: 2598-408X, P-ISSN: 2541-0202

http://unikastpaulus.ac.id/jurnal/index.php/jipd

https://doi.org/10.36928/jipd.v4i2.612

\section{PEMBELAJARAN IPA BERBANTUAN MEDIA AUDIOVISUAL DALAM MENINGKATKAN HASIL BELAJAR SISWA DI MIS AMANAH RUTENG}

\author{
${ }^{1}$ Yosef Firman Narut, ${ }^{2}$ Zephisius R. E. Ntelok \\ ${ }^{1,2}$ Prodi PGSD, FKIP, Universitas Katolik Indonesia Santu Paulus Ruteng \\ e-mail: narutyosef@gmail.com
}

Diterima: 11 Januari 2020, Direvisi: 15 Mei 2020, Diterbitkan: 15 Juli 2020

\begin{abstract}
This study mainly aims to determine the effect of the use of audiovisual media on learning outcomes of fourth grade students at MIS Amanah Ruteng in the 2018/2019 school year. This research includes quantitative research, with the type of experimental research. The design in this study was the prepostest control group design. The sampling technique is done by total sampling, which the entire population of fourth grade is used as a sample. The research sample consisted of 21 students of $4^{\text {th }} \mathrm{A}$ grade as the control class and 21 students of $4^{\text {th }} \mathrm{B}$ grade as the experimental class. The data collection technique in this study was a multiple choice test technique with 30 instruments. The results of the validity test contained 26 valid items and 4 items were invalid with a reliability of 0.932 . Based on the results of the analysis showed the value of $t_{\text {count }}$ was 7.38 and the value of $t_{\text {table }}$ was 2.02 at a significance level of 0.05 . The calculation results showed the value of $t_{\text {count }} 7.38>2.02 \mathrm{t}_{\text {table }}$. This shows that the null hypothesis $\left(\mathrm{H}_{\mathrm{o}}\right)$ was rejected and the alternative hypothesis $\left(\mathrm{H}_{\mathrm{a}}\right)$ was accepted. Based on the results of this study, it was concluded that science learning assisted by audiovisual media was proven to be able to improve student learning outcomes.
\end{abstract}

\section{Keywords: Science Learning, Audiovisual Media, Learning Outcomes}

Abstrak: Penelitian ini bertujuan untuk mengetahui pengaruh penggunaan media audiovisual terhadap hasil belajar IPA siswa kelas IV di MIS Amanah Ruteng tahun ajaran 2018/2019. Penelitian ini termasuk penelitian kuantitatif, dengan jenis penelitian eksperimen. Adapun desain dalam penelitian ini adalah prepostest control group design. Teknik sampling dilakukan secara total sampling, yakni seluruh populasi di kelas IV dijadikan sebagai sampel. Sampel penelitian ini terdiri atas 21 siswa kelas IVA sebagai kelas kontrol dan 21 siswa kelas IVB sebagai kelas eksperimen. Teknik pengumpulan data dalam penelitian ini adalah teknik tes yang berbentuk pilihan ganda dengan 30 butir instrument. Hasil uji validitas terdapat 26 butir soal yang valid dan 4 butir soal yang invalid dengan reliabelitasnya 0,932 . Berdasarkan hasil analisis menunjukan nilai $t_{\text {hitung }}$ sebesar 7,38 dan nilai $t_{\text {tabel }} 2,02$ pada taraf signifikansi 0,05 . Hasil perhitungan menunjukan nilai $t_{\text {hitung }} 7,38>$ nilai $t_{\text {tabel }} 2,02$. Hal ini menunjukkan hipotesis $\mathrm{H}_{\mathrm{o}}$ ditolak dan $\mathrm{H}_{\mathrm{a}}$ diterima. Berdasarkan hasil penelitian dapat disimpulkan bahwa pembelajaran IPA berbantuan media audiovisual terbukti dapat meningkatkan hasil belajar siswa.

Kata Kunci: Pembelajaran IPA, Media Audiovisual, Hasil Belajar

\section{PENDAHULUAN}

IPA merupakan salah satu muatan dalam pembelajaran tematik di Sekolah Dasar (SD) atau sederajat. IPA didefinisikan sebagai sekumpulan pengetahuan tentang objek dan fenomena alam yang diperoleh dari hasil pemikiran dan penyelidikan ilmuwan yang dilakukan dengan keterampilan bereksperimen dengan menggunakan metode ilmiah (Trianto, 2010). Definisi ini memberi pengertian bahwa IPA merupakan cabang pengetahuan 
yang dibangun berdasarkan pengamatan dan klasifikasi data, dan biasanya disusun dan diverifikasi dalam hukum-hukum yang bersifat kuantitatif, yang melibatkan aplikasi penalaran matematis dan analisis data terhadap gejala-gejala alam.

Pembelajaran IPA di SD akan berhasil jika guru memahami perkembangan intelektual siswa SD. Menurut Piaget (Dahar, 2011), perkembangan intelektual siswa SD berada pada tahap operasional konkret, yaitu mereka berpikir atas dasar pengalaman konkret/nyata. Namun dalam pembelajaran IPA, tidak hanya terbatas pada konsepkonsep yang konkret, tapi juga terdapat konsep-konsep yang abstrak.

Salah satu cara untuk mengefektifkan pembelajaran IPA, terutama pada konsepkonsep yang abstrak adalah dengan menggunakan media pembelajaran. Media pembelajaran yang tepat dapat membantu siswa dalam memahami suatu konsep yang abstrak. Jadi, siswa SD sebagai anak operasional konkret masih sangat membutuhkan media konkret untuk menolong perkembangan kemampuan intelektualnya.

$$
\text { Media pembelajaran idealnya }
$$

digunakan untuk menggantikan sebagian besar dari peran guru sebagai pemberi informasi atau pemberi materi pelajaran. Namun, dalam kenyataanya tidak semua guru mengintegrasikan media dalam pembelajarannya. Berdasarkan hasil observasi peneliti di MIS Amanah Ruteng, pembelajaran IPA di sekolah tersebut belum secara optimal menggunakan media pembelajaran yang inovatif. Guru hanya terpaku pada media gambar yang tersaji dalam buku teks. Proses KBMpun masih berpusat pada guru dan berlangsung monoton melalui metode ceramah. Padahal, Kurikulum 2013 telah mengamanatkan pembelajaran konstruktivis yang meninggalkan metode ceramah, dan beralih pada metode yang dapat mengaktifkan siswa untuk memperoleh pengetahuan atau informasi sendiri.

Media pembelajaran yang dikemas dengan baik dapat menarik perhatian siswa dan memotivasi siswa untuk belajar, serta bermanfaat bagi siswa untuk memperoleh dan memperjelas informasi. Sehingga diharapkan dapat berdampak pada peningkatan hasil belajar siswa. Namun, berdasarkan wawancara lanjutan dengan Guru IPA di MIS Amanah Ruteng, ditemukan juga fakta lain bahwa hasil belajar siswa belum maksimal. Hanya terdapat 11 dari 21 siswa yang mendapatkan nilai di atas kriteria ketuntasan minimal (KKM) dari yang telah ditetapkan, yakni 68. Pencapaian hasil belajar yang optimal hanya dapat terlaksana dengan baik bila salah satunya tersedia media pembelajaran yang sesuai dengan kebutuhan siswa, serta dikemas dengan baik dan dapat menarik perhatian siswa.

Media audiovisual merupakan salah satu media pembelajaran yang dapat membantu siswa dalam memahami suatu konsep saat belajar IPA. Pembelajaran IPA yang berbantuan media audiovisual diharapkan dapat membantu siswa untuk memvisualisasikan konsep-konsep abstrak dalam IPA. Pemahaman konsep yang baik tentunya akan berdampak pada peningkatan hasil belajar siswa itu sendiri.

Berdasarkan latar belakang di atas, peneliti telah melakukan penelitian tentang "Pembelajaran IPA Berbantuan Media Audiovisual Dalam Meningkatkan Hasil Belajar IPA Siswa di MIS Amanah Ruteng”. Penggunaan media audiovisual diharapkan dapat meningkatkan hasil belajar siswa, terlebih khusus dalam pembelajaran IPA.

\section{METODE PENELITIAN}

\section{Jenis dan Desain Penelitian}

Penelitian ini menggunakan pendekatan kuantitatif dengan metode eksperimen yang melibatkan dua kelompok, yakni kelompok eksperimen dan kelompok kontrol. Adapun desain dalam penelitian ini adalah prepostest control group design (Sugiyono, 2010). Desain penelitian dapat dilihat pada Tabel 1. 
Tabel 1. Desain Penelitian

\begin{tabular}{cccc}
\hline Kelas & Pretest & Perlakuan & Posttest \\
\hline Eksperimen & $\mathrm{O}_{1}$ & $\mathrm{X}$ & $\mathrm{O}_{2}$ \\
Kontrol & $\mathrm{O}_{3}$ & & $\mathrm{O}_{4}$ \\
\hline
\end{tabular}

\section{Tempat dan Waktu Penelitian}

Penelitian ini telah dilakasanakan di MIS Amanah Ruteng pada bulan April - Mei 2019.

\section{Populasi dan Sampel Penelitian}

Populasi dalam penelitian ini adalah seluruh siswa kelas IV di MIS Amanah Ruteng yang tersebar dalam dua rombongan belajar, yaitu kelas IVA dan IVB. Teknik sampling dilakukan secara total sampling (Sugiyono, 2010), yakni seluruh populasi di kelas IV dijadikan sebagai sampel. Sampel penelitian ini terdiri atas 21 siswa kelas IVA sebagai kelas kontrol dan 21 siswa kelas IVB sebagai kelas eksperimen.

\section{Teknik Pengumpulan Data}

Teknik pengumpulan data dalam penelitian ini adalah teknik tes. Teknik tes yang dilakukan berupa pretest dan posttest.Tes ini diberikan pada dua kelas, baik kontrol maupun eksperimen. Tes diberikan untuk mengukur hasil belajar siswa sebelum dan sesudah KBM.

\section{Instrumen Pengumpulan Data}

Instrumen tes hasil belajar IPA yang digunakan berbentuk pilihan ganda sejumlah 30 butir instrument. Hasil uji validatas isi terdapat 26 butir soal yang valid dan 4 butir soal yang invalid dengan reliabelitasnya 0,932 .

\section{Teknik Analisis Data}

Teknik analisis data dilakukan secara deskriptif kuantitatif. Statitik deskriptif digunakan untuk menghitung mean, median, modus, standar deviasi, grafik dan lain-lain. Selanjutnya dilakukan uji persyaratan analisis, berupa uji normalitas dan homogenitas.

\section{a. Uji Normalitas}

Uji normalitas dilakukan dengan metode Lilliefors dengan menggunakan data dasar yang belum diolah dalam tabel distribusi frekuensi. Data ditransformasikan dalam nilai $\mathrm{Z}$ untuk dapat dihitung luasan kurva normal sebagai probabilitas kumulatif normal. Probabilitas tersebut dicari bedanya dengan probabilitas kumulatif empiris. Nilai beda terbesar digunakan untuk dibanding dengan nilai tabel Lilliefors pada taraf signifikansi 5\% (Purwanto, 2011).

\section{b. Uji Homogenitas}

Uji homogenitas dengan $F$ test two sample for variances dilakukan untuk mengetahui apakah data bersifat homogen atau tidak. Adapun kriteria yang digunakan untuk menarik kesimpulan uji F (Purwanto, 2011), yaitu sebagai berikut:

Jika $F_{\text {hitung }}<F_{\text {tabel}}$, berarti data homogen;

Jika $F_{\text {hitung }}>F_{\text {tabel}}$, berarti data tidak homogen.

Uji lanjutan dilakukan untuk menguji hipotesis penelitian dengan uji t. Adapun kriteria yang digunakan untuk dapat menarik kesimpulan uji t (Sugiyono, 2007), yaitu sebagai berikut:

Jika $t_{\text {hitung }}>\mathrm{t}_{\text {tabel }}$ maka $\mathrm{H}_{\mathrm{o}}$ ditolak dan $\mathrm{H}_{\mathrm{a}}$ diterima;

Jika $\mathrm{t}_{\text {hitung }}<\mathrm{t}_{\text {tabel }}$ maka $\mathrm{H}_{\mathrm{o}}$ diterima dan $\mathrm{H}_{\mathrm{a}}$ ditolak.

\section{Uji Hipotesis}

Dalam penelitian ini, hipotesisnya sebagai berikut.

$H_{o}: \mu_{1} \leq \mu_{2}$ atau tidak terdapat pengaruh penggunaan media audiovisual terhadap hasil belajar IPA siswa.

$\mathrm{H}_{\mathrm{a}}: \mu_{1}>\mu_{2}$ atau terdapat pengaruh penggunaan media audiovisual terhadap hasil belajar IPA siswa.

\section{HASIL DAN PEMBAHASAN}

\section{Hasil Penelitian}

\section{a. Hasil Belajar}

Data hasil belajar IPA siswa diperoleh dari nilai pretest dan posttest, baik pada kelas eksperimen maupun kelas kontrol. Deskripsi data tersaji pada Tabel 2 berikut ini. 
Tabel 2. Deskripsi Data Hasil Belajar IPA

\begin{tabular}{cccccccc}
\hline Perlakuan & N & $\begin{array}{c}\text { Nilai } \\
\text { Min. }\end{array}$ & $\begin{array}{c}\text { Nilai } \\
\text { Maks. }\end{array}$ & Mean Median & Modus & $\begin{array}{c}\text { Std. } \\
\text { Deviasi }\end{array}$ \\
\hline $\begin{array}{c}\text { Pretest } \text { Kelas } \\
\text { Eeksperimen }\end{array}$ & 21 & 52 & 80 & 72 & 72 & 72 & 6,6 \\
$\begin{array}{c}\text { Posttest Kelas } \\
\text { Eksperimen }\end{array}$ & 21 & 76 & 100 & 87,15 & 84 & 84 & 7,41 \\
$\begin{array}{c}\text { Pretest Kelas } \\
\text { Kontrol }\end{array}$ & 21 & 36 & 72 & 52 & 52 & 48 & 8,7 \\
\hline $\begin{array}{c}\text { Posttest Kelas } \\
\text { Kontrol }\end{array}$ & 21 & 48 & 88 & 67,05 & 66 & 72 & 9,67 \\
\hline
\end{tabular}

\section{b. Uji Normalitas}

Uji normalitas data dilakukan dengan menggunakan metode Liliefors. Berdasarkan hasil perhitungan, nilai beda terbesar $\quad(\mid \mathrm{F}(\mathrm{Z})$ - S(Z)|) pada kelas eksperimen adalah 0,189 dengan nilai $\mathrm{L}_{\text {tabel }}$ pada signifikansi $5 \%$ sebesar 0,193. Jadi, dapat disimpulkan data pada kelas eksperimen berdistribusi normal karena nilai $\mathrm{L}_{\text {hitung }} 0,189<\mathrm{L}_{\text {tabel }} 0,193$. Sedangkan nilai beda terbesar $\quad(\mid \mathrm{F}(\mathrm{Z})$ $\mathrm{S}(\mathrm{Z}) \mid)$ pada kelas kontrol adalah 0,115 dengan nilai $\mathrm{L}_{\text {tabel }}$ pada signifikansi $5 \%$ sebesar 0,193. Jadi, dapat disimpulkan data pada kelas kontrol berdistribusi normal karena nilai $\mathrm{L}_{\text {hitung }} 0,115<\mathrm{L}_{\text {tabel }} 0,193$.

\section{c. Uji Homogenitas}

Berdasarkan hasil pengujian $F$ test two sample for variances, dapat diketahui bahwa nilai $F_{\text {hitung }} 1,704<\mathrm{F}_{\text {tabel }} 2,021$ pada taraf signifikansi $5 \%$, maka dapat ditarik kesimpulan data tersebut homogen.

\section{d. Uji Hipotesis}

Berdasarkan hasil uji $\mathrm{t}$, diperoleh nilai $\mathrm{t}_{\text {hitung }}$ sebesar 7,381. Sedangkan nilai $t_{\text {tabel }}$ sebesar 2,021 dengan $\mathrm{db}=(21+21)-2=40$ dan taraf signifikan 0,05 . Nilai $t_{\text {hitung }} 7,381>$ nilai $t_{\text {tabel }}$ 2,021 sehingga hipotesis $\mathrm{H}_{a}$ diterima. Jadi, dapat disimpulkan bahwa terdapat pengaruh penggunaan media audiovisual terhadap hasil belajar IPA siswa.

\section{Pembahasan}

Pembelajaran IPA di SD akan berhasil jika guru memahami perkembangan intelektual siswa SD. Menurut Piaget (Dahar, 2011), perkembangan intelektual siswa SD berada pada tahap operasional konkret, yaitu mereka berpikir atas dasar pengalaman konkret/nyata. Namun dalam pembelajaran IPA, tidak hanya terbatas pada konsepkonsep yang konkret, tapi juga terdapat konsep-konsep yang abstrak (Heyworth, 2003).

Salah satu cara untuk memudahkan siswa dalam memahami konsep abstrak tersebut adalah penggunaan media dalam aktivitas KBM. Media pembelajaran dapat memperjelas konsep-konsep IPA yang sedang dibelajarkan pada siswa SD. Media pembelajaran yang dikemas dengan baik dapat menarik perhatian siswa dan memotivasi siswa untuk belajar serta mengingatkan kembali akan pengetahuan dan keterampilan yang sudah dipelajari. Media pembelajaranpun dapat menghubungkan kembali antara konsepkonsep yang sudah diketahui dengan konsepkonsep yang akan dipelajari. Dengan demikian, keberadaan media pembelajaran dapat bermanfaat bagi siswa untuk memperoleh informasi dan memperjelas informasi (Arsyad, 2017).

Peneliti telah melakukan penelitian untuk mengetahui pengaruh penggunaan media audiovisual terhadap hasil belajar IPA siswa. Berdasarkan hasil penelitian pada kelas IV di MIS Amanah Ruteng, diperoleh rerata nilai posttest pada kelas eksperimen sebesar 87,15 sedangkan kelas kontrol hanya sebesar 67,05. Berdasarkan perbandingan rerata nilai posttest, terlihat bahwa pemberian perlakuan pada kelas eksperimen terbukti lebih baik dalam meningkatkan hasil belajar IPA pada siswa. Lebih lanjut, berdasarkan hasil uji $t$, diperoleh nilai $t_{\text {hitung }}$ $7,381>$ nilai $t_{\text {tabel }} 2,021$ sehingga hipotesis $\mathrm{H}_{\mathrm{a}}$ diterima. Hal ini menggambarkan bahwa penggunaan media audiovisual dalam pembelajaran IPA terbukti berpengaruh dalam meningkatkan hasil belajar siswa.

Pembelajaran IPA dengan media audiovisual merupakan salah cara efektif membantu siswa dalam memahami suatu konsep abstrak dalam IPA. Pembelajaran yang berbantuan media audiovisual dapat membantu siswa untuk memvisualisasikan 
konsep-konsep abstrak dalam IPA. Pemahaman konsep yang baik tentunya berdampak pada peningkatan hasil belajar siswa itu sendiri, seperti terlihat pada hasil uji t. Hasil ini sejalan dengan penelitian Al Fasyih (2015), Alfianti, dkk. (2015), dan Sari (2016) yang menyimpulkan bahwa penggunaan media video dan audiovisual dapat meningkatkan pemahaman konsep siswa pada materi IPA di SD. Pemahaman konsep yang baik inipun berdampak terhadap peningkatan hasil belajar siswa itu sendiri.

Selain dapat meningkatkan hasil belajar, penggunaan media audiovisual juga dapat menggantikan sebagian besar peran guru sebagai pemberi informasi atau pemberi materi pelajaran. Proses KBMpun berlangsung interaktif dan berpusat pada siswa. Hal ini sejalan dengan spirit Kurikulum 2013 yang mengamanatkan pembelajaran konstruktivis, yang dapat mengaktifkan siswa untuk memperoleh pengetahuan atau informasi secara mandiri.

\section{KESIMPULAN}

Berdasarkan hasil uji $t$, diperoleh nilai $t_{\text {hitung }} 7,381>$ nilai $t_{\text {tabel }} 2,021$; sehingga dapat disimpulkan pembelajaran IPA berbantuan media audiovisual terbukti berpengaruh dalam meningkatkan hasil belajar siswa. Pembelajaran yang berbantuan media audiovisual dapat membantu siswa untuk memvisualisasikan konsep-konsep abstrak dalam IPA; sehingga mudah untuk dipahami dan berdampak terhadap peningkatan hasil belajar siswa itu sendiri.

\section{DAFTAR PUSTAKA}

Al Fasyi, M. C. 2015. Pengaruh Penggunaan Media Video terhadap Hasil Belajar IPA Kelas IV SDN Negeri Ngoto. Jurnal Pendidikan Guru Sekolah Dasar, 16 (4), 1 - 8. Diakses 12 Maret 2019 dari http://journal.student.uny.ac.id/ojs/in dex.php/pgsd/article/download/1195/ 1067
Alfianti, V., dkk. 2015. Pengaruh Penggunaan Media Audiovisual terhadap Hasil Belajar IPA di Kelas IV Negeri 66 Pontianak Kota. Jurnal Pendidikan dan Pembelajaran Khatulistiwa, 5 (3), 1 - 10. Diakses 12 Maret 2019 dari http://jurnal.untan.ac.id/index.php/jpd $\mathrm{pb} /$ article/view/14203

Arsyad. 2017. Media Pembelajaran. Jakarta: PT Raja Grafindo Persada.

Dahar, Ratna Wilis. 2011. Teori-Teori Belajar dan Pembelajaran. Jakarta: Erlangga.

Heyworth, R. 2003. Explore Your World with Science Discovery 2. Singapore: Longman.

Sari, D. N. 2016. Pengaruh Penggunaan Media Audiovisual terhadap Hasil Belajar IPA di Kelas IV SD Negeri Pontianak Selatan. Diakses 12 Maret 2019 dari http://jurnal.untan.ac.id/index.php/jpd pb/article/viewFile/14648/13007

Purwanto. 2011. Evaluasi Hasil Belajar. Yogyakarta: Pustaka Belajar.

Sugiyono. 2010. Metode Penelitian Pendidikan (Pendekatan Kuantitatif, Kualitatif dan $R \quad \& \quad D)$. Bandung: Penerbit Alfabeta.

Sugiyono. 2007. Statistika untuk Penelitian. Bandung: Penerbit Alfabeta.

Trianto. 2010. Model Pembelajaran Terpadu. Jakarta: Bumi Aksara. 